\title{
Development of Fast-rise and High-field Kicker Magnet System for Particle Accelerators
}

\author{
E. Nakamura, M. Takayama*, S. Yabukami ${ }^{* *}$, T. Ichinomiya** and S. Nakamura** \\ Accelerator Laboratory, High Energy Accelerator Research Organization (KEK), 1-1 Oho, Tsukuba 305-0801, Japan \\ * Faculty of Systems Science and Technology, Akita Prefectural Univ., 84-4 Aza Ebinokuchi, Tsuchiya, Yurihonjo 015-0055, Japan \\ ${ }^{* *}$ Faculty of Engineering, Tohoku Gakuin Univ., 1-13-1 Chuo, Tagajo, Miyagi 985-8537, Japan
}

\begin{abstract}
Various circular high-energy accelerators designed on the synchrotron concept have recently been operated in order to provide high-intensity beams for the studies in fundamental physics, and those for medical purposes, and to drive reactors. The method of fast injection/ejection method by using pulsed magnets is the most fundamental techniques required in such high-energy accelerators. A kicker magnet system is often used in this method, where the magnetic field is a trapezoid with a fast rise-time of less than $1 \mu$ s and only has a long flattop for short periods of beam injection/ejection. Those should be zero for almost the entire period except for beam injection and ejection. The operation point of magnetic materials has conventionally been designed at very low fields to prevent magnetization from producing a zero field. Operation over the saturation point of magnetic materials was conducted in this study, and favorable performance, which exceeds that of conventional kicker magnet systems, was obtained. The experimental results are presented in the paper.
\end{abstract}

Key words: particle accelerator, injection, ejection, kicker, pulsed magnet, saturation

\section{粒子線加速器用高応答強磁場キッカー電磁石の開発}

\author{
中村英滋・高山正和* ・ 薮上信** 一宮知史 ${ }^{* *} \cdot$ 中村升 ${ }^{* *}$ \\ 高エネルギー加速器研究機構 (KEK) 加速器研究施設, 茨城県つくば市大穂 1-1（テ305-0801） \\ "秋田県立大学システム科学技術学部，秋田県由利本荘市土谷字海老ノ口 84-4（テ015-0055） \\ **東北学院大学工学部，宮城県多賀城市中央 1-13（率985-8537）
}

\section{1.はじめに}

$\mathrm{LHC}^{1)}, \mathrm{J}-\mathrm{PARC}{ }^{2)}$ 等の高エネルギー大強度加速器や医療 用加速器 3), 原子炉駆動用 FFAG 4) など，シンクロトロン 5) を基礎概念とする円形粒子線加速器が本格的に広く稼動し 始めている。これらに必要な基盤技術の 1 つであり粒子線 の入出射法の代表である早い入出射法 6) は概祖 $1 \mu \mathrm{s}$ 以下の 矩形パルス磁場を形成する高応答の電磁石を必要とし，キ ッカー電磁石システム 7)がよく用いられている. 従来技法 においては 0.1 テスラの磁束密度が限界であったが, 磁性 体の非線形特性を利用することで従来技法に基づく性能を 越える成果が得られたのでここに報告する.

キッカーシステムは，間欠的に連なっている高エネルギ 一粒子線群から，対象とする粒子群を選択的に制御する目 的で用いられる機器の総称である 5,8 . 円形高エネルギー 粒子線加速器は, 低エネルギー加速, 中エネルギー加速, 高エネルギー加速という様に段階的に加速するカスケード 方式をとられることが殆どである。低エネルギー加速段階 においては，粒子の速度が低く加速終了までに一定の時間 が必要である。また，1 サイクルで加速できる粒子数が少 ないこともあり, 後段の加速器は前段の加速器の加速終了 を待つとともに, 数サイクルから数百サイクル分の粒子を 順次受け入れることになる. 後段加速器一の粒子群の入射 のためには粒子軌道の変更が必要であり, パルス電磁石が 用いられることが多い。シンクロトロン等の高エネルギー 加速器に置いては，全てを受け入れるまでは受け入れ済み の粒子群は同一軌道を保持していなければならないため,
受け入れ済みの粒子群に影響を与えないように，それらの 間隙に新たな粒子群を入射する必要がある。このため，キ ッカー電磁石を用いる場合はステップ状の磁場が必要とな る(Fig. 1).

高エネルギー粒子線は光速に近い速度で移動しているた め, キッカーシステムは, 起動時間が早くなければならな い. 粒子線加速器の主たる粒子線制御用のキッカーシステ ムは，電界キッカー 9)，磁界キッカー 7)， RF キッカー 10,11) に大別される(Fig. 2). 各々の作用は Lorentz 力に基づく一 般的な荷電粒子の運動方程式で記述される.

\section{Flow Chart of Fast Injection}
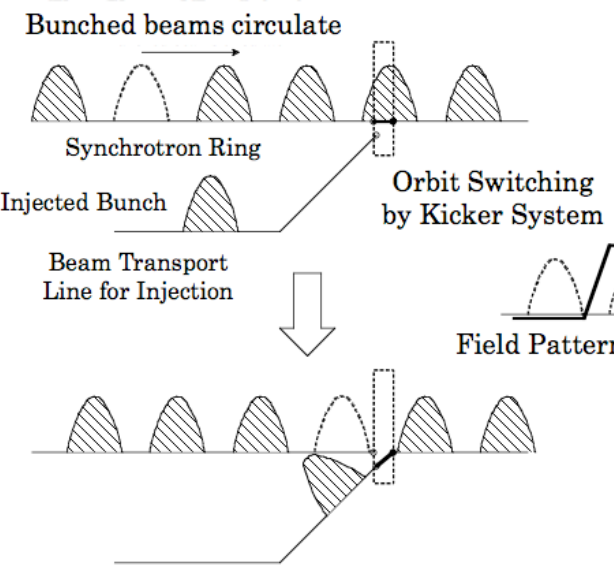

Fig. 1 Schematic of beam handling by using kicker. 


\section{Classification by Field Structure}

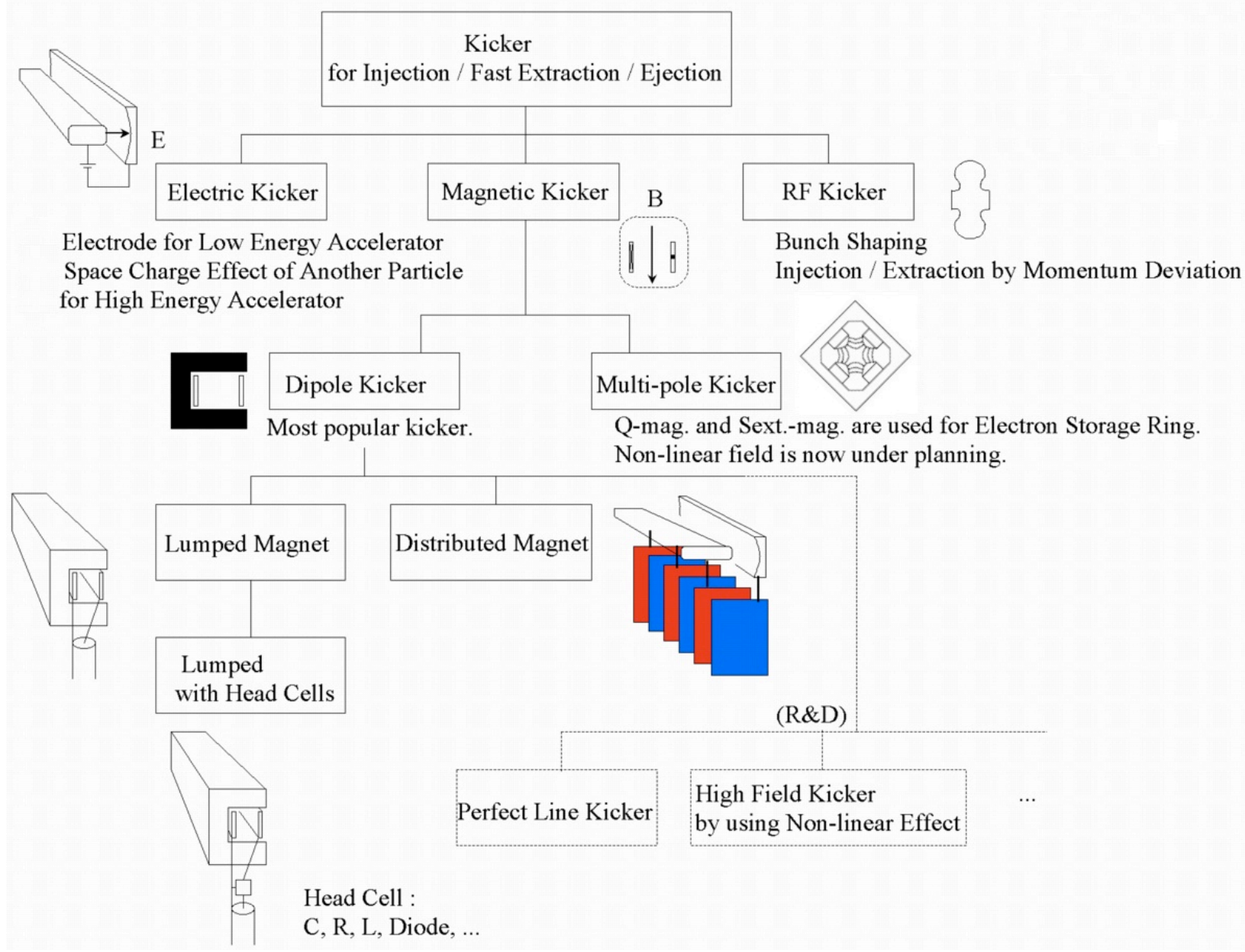

Fig. 2 Classification of kicker systems by using field structures.

断面積が $0.1 \mathrm{~m}$ 角のエリアに場を展開しようとする場 合 (Fig. 3), 高エネルギー粒子線の速度が光速 c に近いた め, その作用比 $E / c B$ で記述され, $B=0.1$ テスラに相当 する電界は $E=30 \mathrm{MV} / \mathrm{m}$ となる. 0.1 テスラの磁場の形 成は比較的容易だが，相当する電界を発生させるためには $3 \mathrm{MV}$ という高電圧が必要となり, 電気絶縁の観点から実 現不可能なる。従って, 高エネルギ一粒子線制御は磁界キ ッカーが殆どとなる. 中・低エネルギー粒子線制御として は, 制御が容易で省電力且つ応答特性に優れる電界キッカ 一が選ばれる．他方， $\mathrm{RF}$ キッカーも電界キッカーの一種 であるが，近年，超伝導空洞により $50 \mathrm{MV} / \mathrm{m}$ という強電界 高周波蓄電が可能となってきたこと 12) もあり, 魅力的な技 術となりつつある.

細かく分類すると，電界キッカーは，静電界キッカー 9), パルス電界キッカー 13)，他の高エネルギー粒子の空間電荷 効果を利用したキッカー ${ }^{14)}$. 磁界キッカーは, 通常の電磁 石と同じ集中定数型，分布定数型 7)，ヘッドセル付き集中 定数型 ${ }^{15,16)}$ ，ストリップライン型 ${ }^{17)}$ ，双子型 ${ }^{18,19)}$, 多極型 20 , 21), 完全整合型 22,23)，マルチターンコイル型 ${ }^{24)}$,

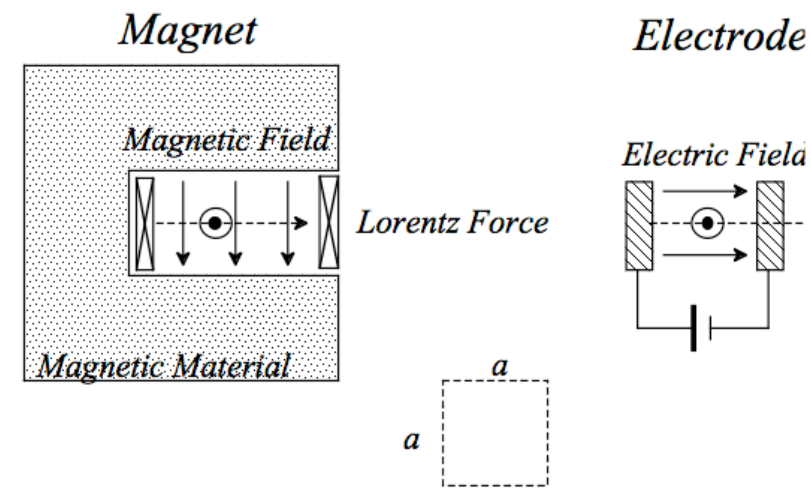

Fig. 3 Comparison of electric and magnetic fields.

強磁場キッカー 25,26$)$ 等が挙げられる。高応答特性を安定 して出力する要求が多いため, 分布定数型 (Fig. 4), 集中 定数型，ヘッドセル付き集中定数型を用いるケースが多 い. 


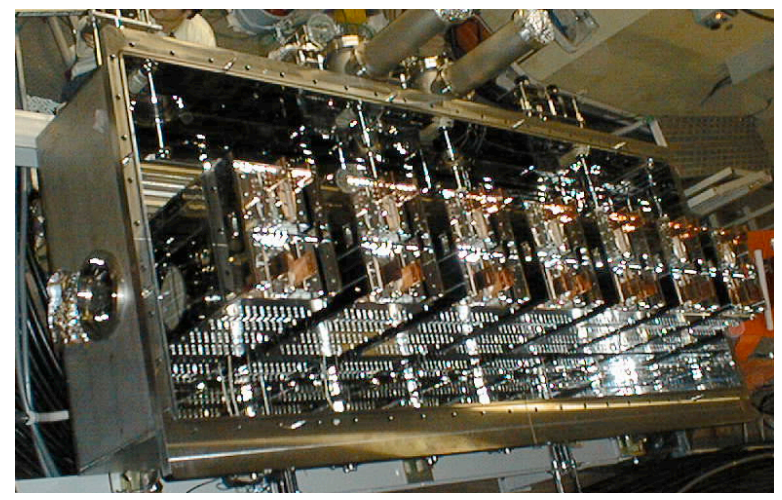

Fig. 4 Actual example of kicker magnets. Seven magnets were installed in vacuum chamber, to deliver $12 \mathrm{GeV}$ proton beams for long baseline neutrino oscillation experiment (K2K).

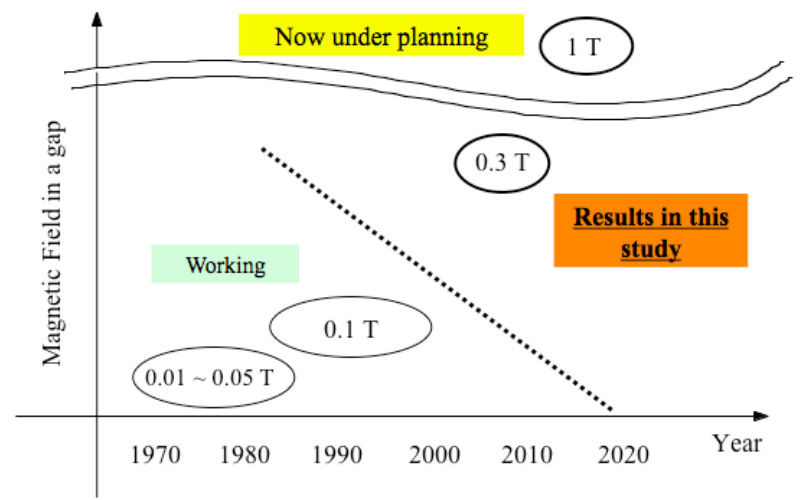

Fig. 5 History of development of kicker systems.

キッカーシステムの開発は 1970 年代を起点とするシン クロトロン加速器の発展とともに歩んできている (Fig. 5). 殆どの加速器稼働時間においてゼロ磁場でなければならず, 磁性体の磁化は高エネルギー粒子線の制御に悪影響を与え るため, 多くのキッカー電磁石は $B-H$ 曲線における初透磁 率可逆領域で設計され, 高真空 27)・高放射線環境下での動 作 ${ }^{28)}$, 早い応答のための高電圧印加に伴う電気絶縁破壊抑 止等の観点からも, 近年までの実働機としては 0.1 テス ラが限界であった. 様々な電磁石構造の工夫も施されてき たが, 高電圧大電流矩形出力電源の限界 29) もあり, 従来技 法では飛躍的な成果は得られなかった. 高エネルギー加速 器の建設が散発的であることもあり綿密な特性評価や個々 の最適化, 高性能化への追求が不十分であったが, 今回, 基礎研究試験環境が整ったこともあり, 磁性体の飽和領域 までの励磁試験を実施した. その結果，0.3 テスラ級の強 磁場を達成することができた，高応答キッカー電磁石シス テムとしては従来技法の 3 倍以上となる成果を挙げられた ことになる. また, 電磁石の構造は最もシンプルな形とな ったため, 高応答化に必要とされていた複雑な構造は不要 となり，電磁石寸法が 1/10 以下になるというコンパクト化 にも成功した. 飽和領域励磁試験の一連の成果のまとめと 関連した新たな展開に関して本論に記述する.

\section{2. 飽和領域を含めたパルス励磁による高応答化}

パルス・高周波伝送の基本原理 ${ }^{30)}$ に基づき，特性インピーダン ス $Z_{0}$ の電源システムからの電圧パルス $V_{f}$ で給電した場合, 1 巻 コイル時のインダクタンス $L$, コイル巻数を $N$ の電磁石一の励 磁電流 $I$ との関係は,

$$
2 V_{f}=N^{2} L \mathrm{~d} I / \mathrm{d} t+Z_{0} I
$$

となる. 電磁石ギャップに発生する磁束を $\Phi$ とすると, 式(1) は 下記のように書き換えられる.

$$
\left(N / 2 V_{f}\right) \mathrm{d} \Phi / \mathrm{d} t+\left(Z_{0} / 2 N L V_{f}\right) \Phi=1 .
$$

この関係式は, 磁束 $\Phi$ とその応答特性を示寸 $\mathrm{d} \Phi / \mathrm{d} t$ の保存則 ともみなせ，それぞれが競合関係にあるとも解釈できる. 高応答特性を維持しつつ強磁場を発生させるには，負荷イ ンダクタンスの低減が必須となる. 負荷電磁石の構造に静 電容量を加え, CL 梯子回路を形成し負荷インピーダンスを 改善する方法 7)もあるが, 実効的には磁束を減らす結果と なるため, 若干の改善に留まる. 近年までは線形的な発想 の下の設計が主であったため, この点が従来技法の限界で あった。

本研究においては, 磁性体の飽和領域近傍の非線形現象 を用い, 実効的なインダクタンスを $1 / 4$ 程度まで低減させ 強磁場を発生させた状態で応答特性も改善することを主眼 とする．飽和領域まで到達するため磁束量は大きく，それ 以降は磁性体の磁束密度の变化は少なくなるためインダク タンス低減につながり高応答化も同時に期待できる.また, 飽和領域近傍での運転を想定する場合従来技法に較べて磁 性体量も減らす事につながり, 電磁石寸法のコンパクト化 にもつながる.この手法は可飽和リアクトルと同じ原理で あり一般な技術であるが，ゼロ磁場形成不能の問題が既成 概念として残っていたこともあり, 高応答の電磁石に適用 したケースとしては初めての技術となる。検証を行うため, KEK-PS で用いた FX キッカー電源 31) を転用し $3 \Omega$ 系を 構成して利用した。電源回路としては非常にシンプルであ り, DC $80 \mathrm{kV}$ 充電器から, 高耐圧同軸線(特性インピーダ ンス $50 \Omega / 16$ 並列)を用いた波形整形線(PFL)に充電し, 必要なタイミングでメインスイッチであるサイラトロン (CX2171：e2V 社)にて短絡状態にし，パルストランス及び パルス伝送線(TL)を経て負荷電磁石に給電する(Fig. 6). 70 $\mathrm{kV}$ の充電電圧と $10 \mathrm{kA}$ という大電流を出力するため, 電 源出力は立ち上がり時間が $150 \mathrm{~ns}$ 程度となっている.

本論においては, 飽和磁束密度が 0.3 テスラのフェラ イト(L6H 材：TDK 社)を用いた場合の結果を示す. 電磁石 寸法は，ギャップ寸法が（幅 $W=140 \mathrm{~mm}) \times($ 高さ $h=50$ $\mathrm{mm}) \times($ 長さ $l=400 \mathrm{~mm}$ ), 磁性体の有効幅が $50 \mathrm{~mm}$ であ り，最もシンプルな集中定数型である(Fig. 7).なお，磁場 計測は，一般的なロングピックアップコイルに誘起される 


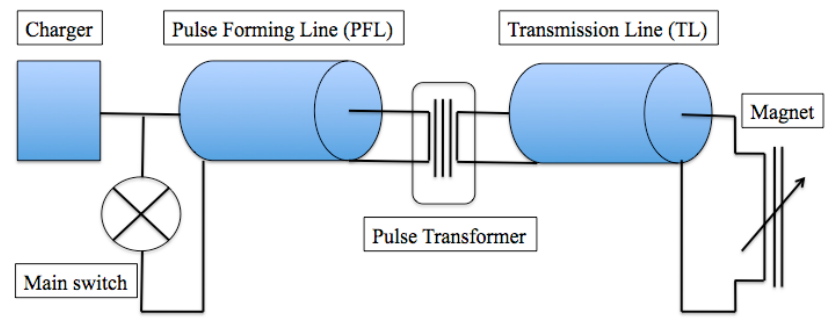

Fig. 6 Equivalent circuit for examination.

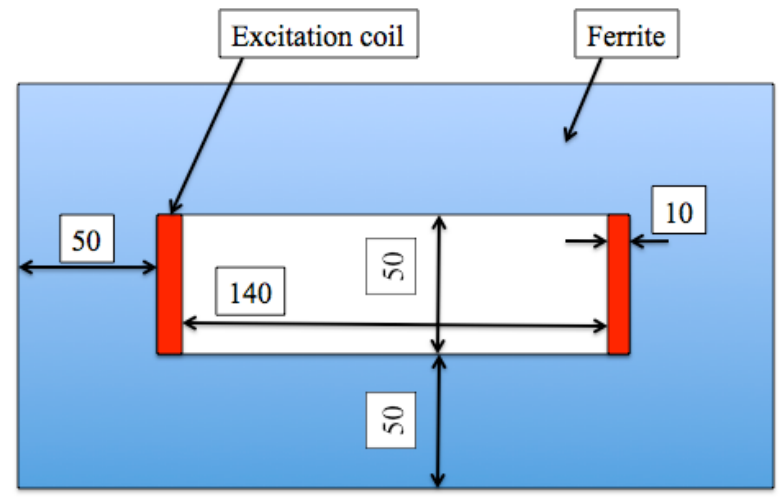

Fig. 7 Cross section of magnet.

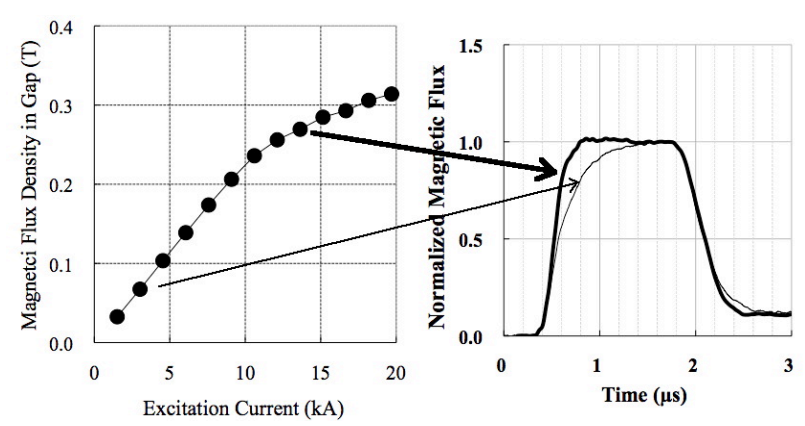

Fig. 8 Comparison of low-current and high-current excitations. Figure at left plots the measured dependence of magnetic field density on excitation current. Saturation point can be observed at $10 \mathrm{kA}$. Figure at right plots the measured waveforms of normalized magnetic flux. A long flattop with a fast rise time is created at high-current excitation.

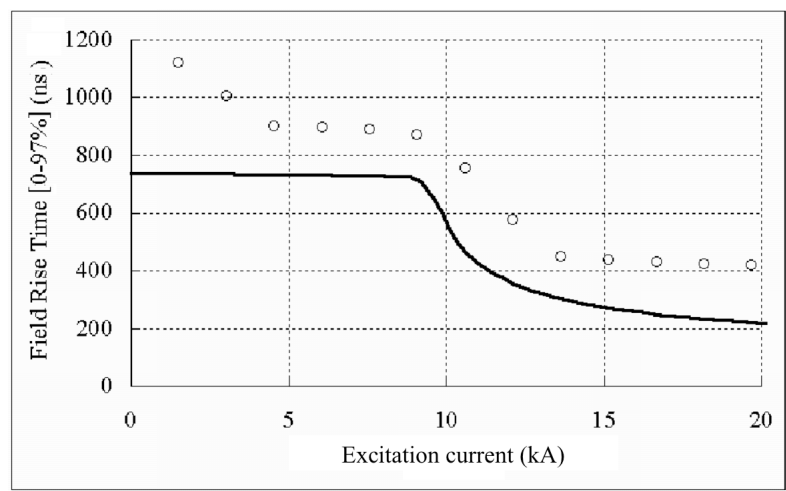

Fig. 9 Measured field rise-time dependence on excitation current. The solid line indicates the calculated result.
電圧を時間積分することで磁束として計測し，残留磁場は ホールプローブを用いて計測した。

Fig. 8 は，励磁電流を変えたときのギャップ内磁束密度 とその波形を示したものである. 磁場波形はフラットトッ プの值で規格化している. 太線で示されるように，早い立 ち上がり時間と長いフラットトップを形成しつつ強磁場を 形成している. Fig. 9 は励磁電流に対する立ち上がり時間 [0-97\%]の実測值を示したものである．励磁電流とともに 立ち上がり時間が改善されていく様子がわかる．実線は式 (2)に磁性体の $B-H$ 曲線データを想定した計算結果であり, 実験結果と同じ傾向を示している. 全励磁電流条件でオフ セットがかかった傾向になっているが，これは電流導入部 (コネクタ）の $0.2 \mu \mathrm{H}$ 程度のインダクタンスによるもの と判明している.この点は今後改善していく予定である.

前述の様なメリットの他にも，飽和による磁束偏在解消 とこれに基づく空間分布自動補正効果，3ターンコイル励 磁での成果等好ましい作用が同時に成立している 24$)$. キッ カー電磁石としては, 各物理量の $1 \%$ のアンバランスが問 題となる. 大電流パルス送電のためには電源システムの特 性インピーダンスを数 $\Omega$ 程度に低くしなければならず， $1 \%$ に相当する $10 \mathrm{~m} \Omega$ のオーダーが問題となる．給電線や電 磁石励磁コイル，及び，高電圧コネクタの接触抵抗等が問 題となるが，上記自動補正効果のためこれらの問題が解消 される．同じような成果は，高インピーダンス系でも確認 されており，低インピーダンス系により低い磁束密度では あるが, $25 \Omega$ 系では $100 \mathrm{~ns}$ [0-95\%] を切る早い立ち上が り時間で 0.22 テスラを達成している ${ }^{26)}$. いずれの実験に おいても，非動作時にホールプローブで電磁石ギャップ内 の残留磁束密度を計測した結果は 0.1 ミリテスラ以下であ った. 残留磁束は周回粒子にとっては不正磁場として働く ため粒子線加速制御においては好ましくなく, 不正磁束を 打ち消すための補正システムを必要とする. 残留磁束密度 の許容值はそれぞれの加速器によって異なるが, 殆どの加 速器において上記の值は補正システムを必要としないレ心゙ ルである. 励磁量を上げて 0.36 テスラの出力を得た結果に おいては, 残留磁束密度が 0.2 ミリテスラとなっていた. 高エネルギー粒子線の制御としては問題ない精度であるが, 更なる強磁場を目指す場合には注意を要する.

高応答特性及び強磁場特性の両方をパルス系で評価する 基準が今現在はない。ここでは，式(2)に準じた高応答特性 $C_{\mathrm{R}}$ と強磁場特性 $C_{\mathrm{A}}$ のパラメーターを設定し, 現存するキ ッカーシステムの性能と比較する. 式(2)において, $t=0$ の ときは $\Phi=0$ であり磁場強度特性が示されない反面, $\mathrm{d} \Phi / \mathrm{d} t$ が存在し，応答特性を示す指標となる。十分時間が経過し たときの磁束 $\Phi$ は磁場強度特性を示寸反面, $\mathrm{d} \Phi / \mathrm{d} t=0$ と なり応答特性を表現できない. 両方の特徽を一括して評価 するため, $G=\alpha C_{\mathrm{R}}+\beta C_{\mathrm{A}}$ という形の指標を用いる. パラ メーター $\alpha, \beta$ は, 磁場特性と応答特性のどちらを重用視 するかによって決める係数である. 本論では，双方とも同 じ評価となるように，基準系において $\alpha=\beta=1$ のときに 
$G=1$ になるように想定する.キッカーシステムにおいて 最もシンプルな $\mathrm{LR}$ 直列負荷（R は整合抵抗）を基準系とす る. $97 \%$ 立ち上がり時間実測值 $\tau 97 \%$, 磁性体の比透磁率が 十分大きいと仮定した従来技法に基づくインダクタンス $L_{0}=\mu_{0} \mathrm{Wl} / \mathrm{h}$, 磁束 $\Phi_{0}$ とした場合, 下記のように設定する.

$$
\begin{aligned}
& C_{\mathrm{A}}=\left(Z_{0} / 2 V_{f} N L_{0}\right) \Phi_{0}, \\
& C_{\mathrm{R}}=\ln [100 /(100-97)]\left(N / 4 V_{f}\right)\left(\Phi_{0} / \tau_{97 \%}\right) .
\end{aligned}
$$

式(3)は式(2)を解析的に解いたときの左辺第 2 項の $t=\infty$ 時, 式(4)は第 1 項の $t=0$ 時の $1 / 2$ の值に相当する.

Fig. 10 は現存する KEK のキッカー電磁石と本研究課 題の成果を示している. 最も一般的な集中定数型電磁石と インピーダンス整合用の抵抗を直列接続した場合を基準と し, この場合は, $C_{\mathrm{A}}+C_{\mathrm{R}}=1$ の直線上に乗る. より右上に 位置すれば最適化・高性能化とみなすことができる.一般 の電磁石は, 抵抗器を用いないため, $C_{\mathrm{A}} / 2+2 C_{\mathrm{R}}=1$ が理想 上限となる. 従来技法に基づくキッカー電磁石システムに 関しては, 電源の立ち上がり時間が影響してくるため, 理 想ラインには到達できず, 左下に位置する. 本研究課題 の成果の幾つかはそれぞれの上限ラインを越えており, 従 来技法以上の性能を発揮できたとみなせる.

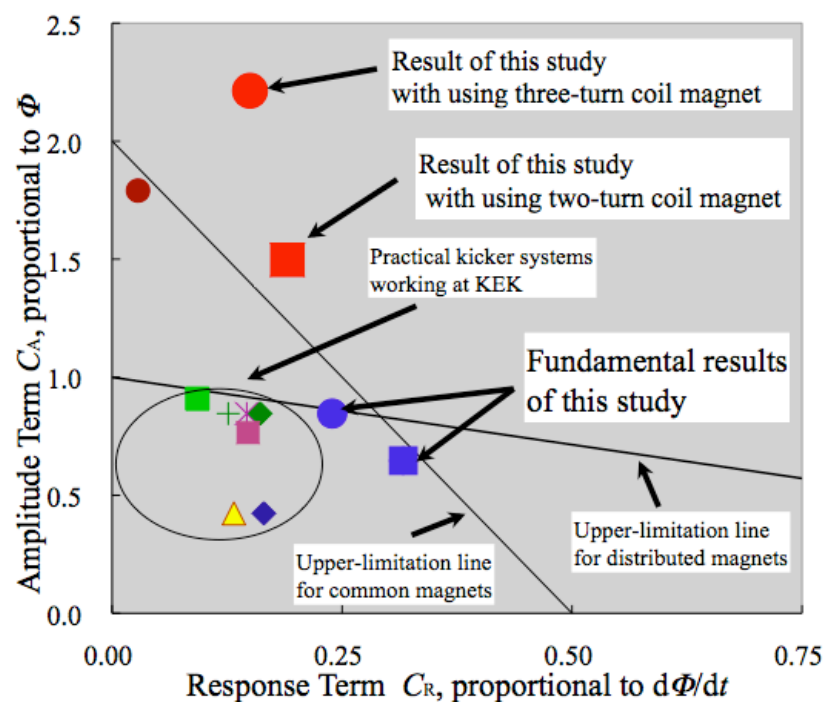

Fig. 10 Performance of kicker systems in KEK. The horizontal axis indicates a response term $C_{\mathrm{R}}$, and the vertical axis indicates an amplitude term $C_{\mathrm{A}}$. The thin line $C_{\mathrm{A}}+C_{\mathrm{R}}=1$ indicates the ideal case for lumped magnets with an impedance-matched resistor. The solid line $C_{\mathrm{A}}+$ $C_{\mathrm{R}} / 1.75=1$ indicates that for distributed magnets. The existing kicker systems in KEK, which are designed based on the conventional concept, are located in the solid circles. The small circle, which is located near $C_{R}=0$, is an example of an ordinary magnet.

\section{3. 今後の課題と展開}

前章においてパルス電磁石の強磁場・高応答化に関する技法の 基本原理とこれに基づく高応答強磁場化の一例を実験的に示し, その可能性を見出した. 下記の課題をクリアしていくことで, 更 なる飛躍的な高性能化が可能であると考えられる.

\section{1 磁性材料の選定}

磁場特性の向上を目指すためには, 磁性材料の選定及び最適化 が重要な鍵となる. 高透磁率, 高飽和磁束密度, 且つ, 磁化しに くい材料が求められる. 従って, 殆どのケースにおいて軟磁性材 料が用いられる. キッカー電磁石には, 高真空環境下での動作が 多くアウトガス ${ }^{22)}$ の少ないフェライトを用いるのが殆どであるが, 純鉄やアモルファス等の高飽和磁束密度, 高透磁率を有する材料 も再び検討寸る価值がある. その際は, ゼロ磁場形成条件が必須 であるため, 残留磁束の見極めが必要となる. 今回は, 従来技法 で用いられてきたフェライトを中心に検証を実施したが，様々な 磁性体での試行を予定している.

\section{2 計測技法}

計測技法の開発も重要である．従来技法においては，最もシン プルなピックアップコイルによる誘導電圧計測が殆どを占めてい たが, 本研究の 0.36 テスラ試験等においては出力が過剰となり, ピックアップコイル自体に $10 \mathrm{kV}$ 近い高電圧が誘起され電気絶縁 破壊を引き起こす結果となった. 放電防止策としては絶縁材を用 いられてきたが, 絶縁材の誘電損失による波形計測精度, 特に過 渡現象の計測精度が劣化するため, 計測に関する基礎理論の再構 築による補正, もしくは, 光学干渉計 ${ }^{33)}$ 等の異なる計測技法の登 用・開発が必要となってくる.

\section{3 高繰り返し化}

粒子線加速器の性能向上の一つとして, 加速器の運転サイクル の高繰り返し化 ${ }^{34)}$ が求められる. 高繰り返し高電圧大電流電源の 開発が主要課題となる.

また，磁性体の損失の問題も浮上してくる. キッカー電磁石シ ステムは短い時間だけの励磁であり, 今日までの粒子線加速器で は最大でも $10 \mathrm{~kW}$ のパルス出力しかなく, その殆どは整合抵抗 器で消費され, 磁性体での損失は少ない, 繰り返しを上げると磁 性体の損失による発熱の問題が浮上する. 可能な限りの強磁場を 形成したいため, エアギャップを狭め, キッカー電磁石本体を真 空環境で動作させることが多い. 真空環境下では熱絶縁効果が大 きく, 数十 $\mathrm{W}$ でも電磁石の温度上昇に寄与してしまう. 温度上昇 による磁性の変化はもとより, 磁性材料からの不純物放出が多く なり高真空環境を維持できなくなる等の問題が生じる. 冷却もし くは放熱システムが必要となるが, 設置空間が限られるため, 慎 重な検討を要する.

\section{4 電源開発}

早い立ち上がり時間を有する励磁電源の開発も必須である. 最 重要課題としては, 高電圧パルス出力が可能なスイッチの開発で ある. 矩形出力に関して現存する最高性能はサイラトロンを用い た結果であり, $100 \mathrm{kA} / \mu \mathrm{s}{ }^{35,36)}$ がめやすとなっている. ハーフサ イン波出力では半導体素子 37) も $250 \mathrm{kA} / \mu \mathrm{s}$ まで可能である. 

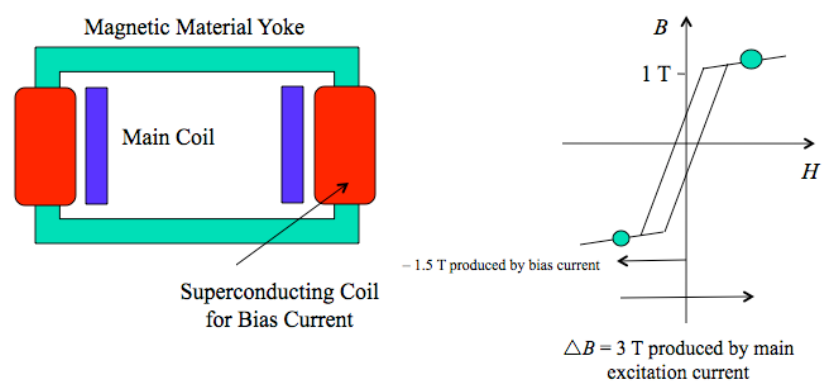

Fig. 11 Schematic of super high field kicker. Figure at left shows magnet structure. Figure at right figure indicates material operation region on the $\mathrm{B}-\mathrm{H}$ curve.

\subsection{B-H 曲線のフルレンジ利用}

変圧器の原理と同様, 補巻き線を設置しバイアス構造を 施し $B-H$ 曲線を最大幅で利用することも考えられ， 3 テス ラ級の超強磁場キッカーの可能性もある(Fig. 11). パルス 運転であるため, 主回路の電力や冷却の問題も殆どない. しかしながら, 電磁石はエアギャップであるため, 莫大な バイアス電流が必要となる. 近年, 加速器開発においても 目覚ましい発展を遂げた超伝導技術 38,39$)$ の登用が打開策の 鍵になる. 他方, テスラ級の粒子線制御は制動放射 40 ) 等悪 影響を引き起こす可能性を残す. 制御対象のビーム物理, ビームオプティクス ${ }^{41)}$ の最適化も重要な研究要素となる.

\section{4. まとめ}

磁性体の飽和現象を過渡応答電磁石に適用し, 高応答且 つ強磁場のキッカー電磁石システムの可能性を見出した. 近年の粒子線加速器は, 超伝導技術の発達により主要電磁 石の強磁場化はもとより加速器自体のコンパクト化も進ん でいる. それに伴い, 粒子線制御技術の飛躍的な向上や高 効率化が求められる. 本研究においては, 磁性体の一部の 特性を利用して成果を挙げる事ができたが, 磁性体には未 だ魅力的な多くの特性がある. 本論においては磁性体の一 方向のみの物性を利用したが, パルス励磁と直流励磁等動 作時間帯（動作周波数帯）の差や, 材料特性の空間的異方 性, また, これらを組み合わせて作用させる事で新たな機 能結合型電磁石の可能性も拓けてくる. 磁性体は誘電特性 も有しており, 今日まで着目されてこなかった磁気特性の 時間・空間・物性等の多次元的活用による更なる高性能機 の開発とこれらにより新たな高エネルギ一粒子線制御方法 の開発が期待される.

謝辞 御協力戴いた KEK-PS 加速器 のスタッフに厚く御 礼申し上げます。この研究は, 科研費 21540310 の助成を 受けた成果である.

\section{References}

1) http://user.web.cern.ch/user/Welcome.asp (As of Oct. 14, 2010).

2) http://j-parc.jp/Acc/ja/index.html (As of October 14, 2010).

3) http://www.nirs.go.jp/index.html (As of October 14, 2010).

4) Y. Mori: Nucl. Instr. and Meth. A 451, 300 (2000).

5) Y. Kimura: High energy accelerators, KYORISU SYUPPAN CO., LTD, July 25, 2008, ISBN 9784320033825.

6) K. Takata, et al.: KEK-PrePr. KEK-76-21 (1976).

7) D. Fiander: Proc. US Part. Accel. Conf., 1971. CERN/MPS/SR71-5.

8) http://www-ps.kek.jp/kekps/12GeV/ (As of Oct. 14, 2010).

9) T. H. Luo, et al.: Proc. IPAC'10, 3792, (2010).

10) Y. Iwashita: Proc. EPAC2006, 759 (2006).

11) T. Kurita, et al.: Proc. EPAC2006, 1771 (2006).

12) F. Fukuta, K. Saito: Proc. Particle Accelerator Society Meeting 2009, 962 (2009).

13) E. Nakamura: Proc. the $9^{\text {th }}$ Accelerator and related technology for application, (2007).

14) V. D. Shiltsev: Nucl. Instr. and Meth. A 374, 137 (1996).

15) M. Kikuchi, et al.: Nucl. Instr. and Meth. A 499, 8 (2003).

16) T. Oki: Nucl. Instr. and Meth. A 607, 489 (2009).

17) T. Naito, et al.: Nucl. Instr. and Meth. A 571, 599 (2007).

18) E. Nakamura, et al.: Proc. the $4^{\text {th }}$ Annual Meeting of Particle Accelerator Society of Japan and the $32^{\text {nd }}$ Linear Accelerator Meeting in Japan, 787 (2007).

19) K. L. Tsai, et al.: Proc. IPAC'10, 1796 (2010).

20) T. Miyajima, et al.: Nucl. Instr. and Meth. A 581, 589 (2007).

21) Y. Takasu et al.: KEK-PS Internal Report ASN-494 (2006) (in Japanese).

22) T. S. Mattison, et al:: Proc. IEEE, 1915 (1996).

23) H. Hahn, et al.: Proc. PAC2001, 3705 (2001).

24) E. Nakamura: Nucl. Instr. and Meth. A 618, 22 (2010).

25) M. J. Barnes, G. D. Wait: Proc. EPAC1994, 2544 (1994).

26) E. Nakamura: Nucl. Instr. and Meth. A 612, 50 (2009).

27) T. Kubo, et al.: J. Vac. Soc. Jpn., 41, 217 (1998).

28) K. Makita, et al.: J. Mag. Soc. Jpn., 28, 326 (2004).

29) E. Nakamura, et al.: Proc. the $16^{\text {th }}$ SI Device Symposium, 31 (2003) (in Japanese).

30) E. Ezura: Introduction to Microwave Transmission and Signal Analysis (Accelerator Design Series), KEK Internal 2003-3, Sep. 2003A.

31) E. Nakamura: KEK-PS internal report, Accelerator Study Note 475, (2004) (in Japanese).

32) T. Kubo, et al.: Proc. the $10^{\text {th }}$ Ultra High Vacuum Technology for Accelerator Science and Storage Rings, p7 (2004) (in Japanese).

33) E. Efstathiadis, et al.: Nucl. Instr. and Meth. A 496, 8 (2003).

34) Y. Ishi, et al.: Nucl. Instr. and Meth. A 472, 639 (2001).

35) English Electric Valve Company Limited, Thyratron databook.

36) English Electric Valve Company Limited, Thyratron technical reprints.

37) A. Tokuchi, et al.: Nucl. Instr. and Meth. A 374, 352 (1996).

38) L. G. Isaeva, et al.: Nucl. Instr. and Meth. A 416, 253 (1998).

39) R. Arai, et al.: Nucl. Instr. and Meth. A 254, 317 (1987).

40) R. Hajima, et al.: KEK Report 2007-7 (2008).

41) M. Shimada, et al.: Nucl. Instr. and Meth. A 575, 315 (2007).

2010 年 10 月 18 日受理, 2010 年 12 月 21 日再受理， 2011 年01月 17 日採録 